\title{
PHYSICAL CHARACTERISTICS AND MICROBIAL LOAD OF CHILLED HOLSTEIN BULL SEMEN DILUTED IN PROPOLIS CONTAINED EXTENDER
}

\author{
Awad A. Zaghloul
}

\author{
Department of Animal and Poultry Physiology, Division of Animal and Poultry Production, Desert Research \\ Center, Matariya, Cairo, Egypt
}

\section{SUMMARY}

The current pilot study was carried out to evaluate the efficiency of supplementing bovine semen extender with propolis extract on cooled semen physical characteristics and microbial contamination. Six Holstein Friesian bulls aged 4-6 years, and average body weights of 1041.7 $\pm 58.3 \mathrm{Kg}$ were used. Eighteen ejaculates were collected from the bulls (3 ejaculates each).Thereafter, the ejaculates were pooled and diluted. The pooled specimens were further split into the following five groups: control, $1 \mathrm{ml} / \mathrm{L}$ streptomycin sulfate plus $1000000 \mathrm{IU}$ penicillin, $5 \mu \mathrm{L} / \mathrm{ml}$ propolis extract, $10 \mu \mathrm{L} / \mathrm{ml}$ propolis extract, $20 \mu \mathrm{L} / \mathrm{ml}$ propolis extract. All semen groups were subjected to cooling preservation for $48 \mathrm{~h}$ at $5^{\circ} \mathrm{C}$, during which sperm physical properties were evaluated. Formation of total colony forming unite (CFU) was also determined. The results showed that propolis extract supplementation improved $(P<0.05)$ all sperm physical characteristics, in a dose - depending manner, over preservation time. Further, the control group exhibited total $C F U$ higher $(P<0.05)$ than all treated specimens. These results imply the possibility of using propolis extract as a sufficient alternative to conventional synthetic antibiotics in bovine semen extenders.

\section{Keywords: Propolis, semen, extender, physical characteristics}

\section{INTRODUCTION}

Artificial insemination (AI) has been widely used as reliable tool for reproduction in cattle under intensive animal production systems. In the meantime, successful AI depends not only upon maximizing the initial fertility of fresh ejaculates, but also its maintenance during chilled or frozen storage (Jha et al., 2013). However, the fertilizing capacity of cooled spermatozoa has been reported to decrease over chilling-preservation time along with both sperm motility and morphology (Alam et al., 2005 and Munsi et al., 2007). Long preservation of chilled semen has been reported to expose sperms to the drastic effects of spontaneous lipid peroxidation, which is associated with loss of motility and increased sperm damage (e.g. loss of membrane fluidity and increase in DNA breakage) in different mammalian species (Foote et al., 2002 and Agarwal et al., 2003).

Microbial contamination of fresh and preserved semen represents another constrain in applying AI, as it may lead to rapid decline in sperm motility and subsequent fertility (Shukla, 2005 and Morrell, 2006). Semen contamination has been reported to occur at any time right from collection through the various steps involved in processing and preservation. Although zero risk does not exist in the biological world, but it should be as close to it as possible (Sannat et al., 2015). The artificial vagina, the glass wares, semen extender and laboratory environment are some of the common sources that contribute to the bacterial load of semen during processing (Morrell, 2006).
Propolis is a natural resinous product that honeybees collect from several plants and mix it with beeswax and salivary enzymes (B_glucosidase) (Marcucci et al., 1995 and Cardoso et al., 2011).

Bees use propolis on their hives as protection against predators and microorganisms, to repair damage, as a thermal isolator, and to build aseptic locals to prevent microbial infection of larva (Marcucci et al., 1995; Bankova, 2005 and Fokt et al., 2010). Due to its chemical composition, propolis has been used by humans to meet the needs of health and food preservation (Umthong et al., 2011). In the last years the interest in this complex natural product has increased due to its broad spectrum of biological properties (Fokt et al., 2010). Propolis comprises complexity of compounds which play a role in antiviral protection as well as antimicrobial activity due to its major effect against several bacterial strains (Marcucci et al., 1995; Kujumgiev et al., 1999; Mirzoeva et al., 1997 and Scazzocchio et al., 2006). Recently, several studies have shown the effect of propolis from different geographic origin against different fungi, particularly of clinical interest. Additionally, the polyphenols in propolis extract has been reported to possess a potent antioxidant activity (Scalbert et al., 2005; Almaraz-Abarca et al., 2007 and Nader et al., 2010). The current pilot investigation was undertaken to evaluate the efficiency of supplementing bovine semen extender with propolis ethanolic extract on chilling preservation of spermatozoa. The potential antimicrobial effect of propolis supplementation was also investigated. 


\section{MATERIALS AND METHODS}

\section{Animals and management:}

The current study was carried out at the Artificial Insemination Center, belonging to the West Noubaria Rural Development Project, Alexandria, Egypt. Six Holstein bulls aged 4-6 years, and average body weights of $1041.7 \pm 58.3$ were used. The bulls were kept under intensive breeding management, where Egyptian clover, Trifolium alexandrinum, was provided ad lib., and a concentrate mixture was presented to meet the bulls' protein and energy requirements (NRC, 2001). Before executing the experiment, the bulls were clinically examined and were found free of disease or reproductive disorders.

\section{Semen extender and propolis extract:}

Semen extender was freshly prepared prior to semen collection. Each $100 \mathrm{ml}$ of the extender was composed of $3.025 \mathrm{~g}$ tris (hydroxymethyl amino methane), $1.675 \mathrm{~g}$ citric acid, $0.75 \mathrm{~g}$ glucose and was further supplemented with $20 \%$ egg yolk to reach a final $\mathrm{pH}$ of 7.4.

Extraction of red propolis was carried out according to the method of Morsy et al. (2013). Filtration, purification and preservation of the propolis extract were conducted according to the method of Morsy et al. (2015).

\section{Semen collection:}

A total of 18 ejaculates were collected from the bulls (three ejaculates from each bull) during the experimental period. Collection of semen was conducted using an artificial vagina according to the method of Barszcz et al. (2012). Upon collection, the ejaculates that showed contamination with urine, strange color or odder were discarded.

Immediately after collection, the ejaculates were transported to a fully equipped laboratory in a warm water bath adjusted at $37^{\circ} \mathrm{C}$.

The ejaculates of each collection session were pooled immediately after collection, and the pooled samples were further diluted 1:8 with the previously mentioned extender. Thereafter, the diluted semen specimens were split into the following five groups: control, $1 \mathrm{ml} / \mathrm{L}$ streptomycin sulphate plus $100000 \mathrm{IU}$ penicillin, $5 \mu \mathrm{l} / \mathrm{mL}$ propolis extract, $10 \mu \mathrm{l} / \mathrm{ml}$ propolis extract, $20 \mu \mathrm{l} / \mathrm{mL}$ propolis extract. All control and treated semen groups were further stored at $5^{\circ} \mathrm{C}$ for $48 \mathrm{~h}$, during which semen physical properties were evaluated .

\section{Semen evaluation:}

Physical characteristics of all semen groups were evaluated throughout the $48 \mathrm{~h}$ of preservation at times 0,24 and $48 \mathrm{~h}$, respectively. Percentage of sperm motility, dead spermatozoa and sperm abnormalities were recorded according to Salisbury et al. (1978). For acrosomal damage estimation, spermatozoa were fixed in a solution of $0.2 \%$ glutaraldehyde and integral acrosome percentage was estimated according to Johanson et al. (1976). Simultaneously with physical properties evaluation, chilled semen of control and treated groups were analyzed for presence of microbial activity at 0,24 and $48 \mathrm{~h}$ of cooled storage. Determination of microbial activity was performed by counting the colony forming unite (CFU) as described by Sannat et al. (2015). The microbial activity was monitored on nutrient agar medium, and total CFU $\left(\mathrm{x} \mathrm{10} 0^{3}\right)$ were counted.

\section{Statistical analysis:}

All parametric data were subjected to Analysis of Variance (ANOVA) using Minitab (Version 10, Minitab Inc., USA) statistical package. The effect model used was Yijk $=\mu+\mathrm{Gi}+\mathrm{Tj}+\mathrm{GTij}+$ eijk

Where;

Yijk $=$ The observation taken on sperm criteria (ijk)

$\mu=$ Overall mean,

$\mathrm{Gi}=\mathrm{A}$ fixed effect of the (i) treatment

$\mathrm{Tj}=\quad$ A fixed effect of the (j)observation time

GTij $=$ The interaction effect between treatment and observation time eijk $=\begin{aligned} & \text { Random error assumed to be normally distributed with } \\ & \text { mean }=0 \text { and variance }=\text { Ó2e. }\end{aligned}$

The comparisons between means were determined by Fisher's least significant difference (LSD) according to Steel and Torrie (1980). The data are presented as mean \pm SEM.

\section{RESULTS AND DISCUSSION}

Data for the effect of adding different levels of propolis extract to semen extender of Holstein bulls on cooled semen physical properties are expressed in Table (1). The results showed that mean values of sperm motility were significantly $(\mathrm{P}<0.05)$ affected by the semen additive. The highest mean values of sperm motility were observed in both synthetic antibiotic and the high dose $(20 \mu \mathrm{l} / \mathrm{ml})$ proplis extract semen groups, while the lowest mean values were observed in the low dose $(5 \mu \mathrm{l} / \mathrm{ml})$ semen group with values $93 \pm 1.2,88 \pm 1.8$ and $76 \pm 3.7 \%$,respectively. Moreover, time of preservation had a significant $(\mathrm{P}<0.05)$ effect on sperm motility all semen treatment groups with highest $(\mathrm{P}<0.05)$ values recorded at $\mathrm{T}_{0}$ and lowest $(\mathrm{P}<0.05)$ values at $\mathrm{T}_{48}($ Table 1$)$. On the other hand neither mean values of live sperm $(\%)$, intact acrosome (\%) normal sperm (\%) were significantly $(\mathrm{P}<0.05)$ affected by the treatment prior to cooling $\left(\mathrm{T}_{0}\right)$. However, all previously criteria were drastically declined $(\mathrm{P}<0.05)$ with progression of preservation time (Table1). The results also showed that the control semen group exhibited colony forming unit $(\mathrm{CFU})$ higher $(\mathrm{P}<0.05)$ than all treated semen groups. However, no significant effect was observed among the different levels of proplis extract groups in the CFU (Figure 1).

The present pilot investigation is the first trial to address the effect of adding propolis extract to semen extender on physical properties and microbial load of chilled bull sperm. The results showed that proplis extract significantly affected all preserved sperm characteristics in a dose-depending manner. The highest mean values were recorded in the high dose 
of propolis extract group, whereas the lowest values were observed in the low dose group with progression of storage time. The results also demonstrated the efficiency of adding propolis extract to semen extender in reducing the microbial load of cooled semen. Long preservation of chilled semen has been reported to expose sperms to the drastic effects of spontaneous lipid peroxidation, which is associated with loss of motility and increased sperm damage (Foote et al., 2002 and Agarwal et al., 2003).

Propolis has versatile biological and pharmacological activities, such as antibacterial, antioxidant, antiviral, antifungal, anti-inflammatory, antitumoral, and immunomodulatory (Alencar et al., 2007 and Sforcin et al., 2011). The biological activity of propolis may vary, together with its chemical composition, as it comprises numerous constituents. These comprise polyphenols (flavonoid aglycones, phenolic acids and their esters, phenolic aldehydes, alcohols, and ketones), sesquiterpene quinones, coumarins, steroids, amino acids, and inorganic compounds (Alencar et al., 2007). The enhancement in semen properties observed in the high dose group in the current investigation could be attributed to

Table 1. Effect of adding different levels of propolis extract toHolstein bulls' semen extender on cooled semen physical characteristics (mean \pm SEM)

\begin{tabular}{|c|c|c|c|c|c|c|}
\hline \multirow[b]{2}{*}{ Parameters } & \multirow[b]{2}{*}{ Time } & \multicolumn{5}{|c|}{ Treatment groups } \\
\hline & & Control & $\begin{array}{l}\text { Synthetic } \\
\text { antibiotics }\end{array}$ & $\begin{array}{l}\text { Propolis extract } \\
(20 \mu \mathrm{l} / \mathrm{ml})\end{array}$ & $\begin{array}{l}\text { Propolis extract } \\
(10 \mu \mathrm{l} / \mathrm{ml})\end{array}$ & $\begin{array}{c}\text { Propolis extract } \\
(5 \mu \mathrm{l} / \mathrm{ml})\end{array}$ \\
\hline \multirow{3}{*}{ Motility (\%) } & $\mathrm{T}_{0}$ & $94.0 \pm 1.0^{\mathrm{a}, \mathrm{A}}$ & $93.0 \pm 1.2^{\mathrm{ab}, \mathrm{A}}$ & $88.0 \pm 1.2^{\mathrm{ab}, \mathrm{A}}$ & $86.0 \pm 1.9^{\mathrm{b}, \mathrm{A}}$ & $76.0 \pm 3.7^{\mathrm{c}, \mathrm{A}}$ \\
\hline & $\mathrm{T}_{24}$ & $60.5 \pm 0.5^{\mathrm{c}, \mathrm{B}}$ & $87.0 \pm 1.4^{\mathrm{a}, \mathrm{B}}$ & $78.0 \pm 0.5^{\mathrm{a}, \mathrm{B}}$ & $73.5 \pm 1.3^{\mathrm{b}, \mathrm{B}}$ & $59.0 \pm 2.8^{\mathrm{c}, \mathrm{B}}$ \\
\hline & $\mathrm{T}_{48}$ & $27.0 \pm 1.2^{c, C}$ & $81.0 \pm 1.8^{a, C}$ & $68.0 \pm 1.2^{b, C}$ & $61.0 \pm 1.0^{\mathrm{c}, \mathrm{C}}$ & $42.0 \pm 2.0^{\mathrm{d}, \mathrm{C}}$ \\
\hline \multirow{3}{*}{ Live Sperm (\%) } & $\mathrm{T}_{0}$ & $86.0 \pm 1.3^{\mathrm{A}}$ & $86.4 \pm 1.6^{\mathrm{A}}$ & $82.6 \pm 3.4^{\mathrm{A}}$ & $82.0 \pm 2.7^{\mathrm{A}}$ & $77.6 \pm 2.6^{\mathrm{A}}$ \\
\hline & $\mathrm{T}_{24}$ & $58.6 \pm 0.7^{\mathrm{c}, \mathrm{B}}$ & $78.3 \pm 0.9^{\mathrm{a}, \mathrm{B}}$ & $74.8 \pm 1.3^{\mathrm{a}, \mathrm{AB}}$ & $66.9 \pm 1.5^{\mathrm{b}, \mathrm{B}}$ & $57.5 \pm 3.0^{\mathrm{c}, \mathrm{B}}$ \\
\hline & $\mathrm{T}_{48}$ & $31.2 \pm 1.2^{\mathrm{c}, \mathrm{C}}$ & $70.2 \pm 0.7^{\mathrm{a}, \mathrm{C}}$ & $67.0 \pm 2.3^{\mathrm{a}, \mathrm{B}}$ & $51.8 \pm 0.9^{b, C}$ & $37.4 \pm 3.4^{\mathrm{c}, \mathrm{C}}$ \\
\hline \multirow{3}{*}{$\begin{array}{l}\text { Intact acrosome } \\
(\%)\end{array}$} & $\mathrm{T}_{0}$ & $85.6 \pm 1.5^{\mathrm{A}}$ & $83.2 \pm 1.9^{\mathrm{A}}$ & $86.8 \pm 1.2^{\mathrm{A}}$ & $86.4 \pm 1.6^{\mathrm{A}}$ & $84.8 \pm 1.9$ \\
\hline & $\mathrm{T}_{24}$ & $63.8 \pm 0.8^{\mathrm{b}, \mathrm{B}}$ & $80.0 \pm 1.0^{\mathrm{a}, \mathrm{AB}}$ & $80.9 \pm 1.0^{\mathrm{a}, \mathrm{AB}}$ & $78.7 \pm 1.0^{\mathrm{a}, \mathrm{B}}$ & $66.4 \pm 3.1^{b}$ \\
\hline & $\mathrm{T}_{48}$ & $42.0 \pm 1.2^{b, C}$ & $76.8 \pm 1.8^{\mathrm{a}, \mathrm{B}}$ & $75.0 \pm 1.5^{\mathrm{a}, \mathrm{B}}$ & $71.0 \pm 1.0^{\mathrm{a}, \mathrm{C}}$ & $46.0 \pm 4.0^{b}$ \\
\hline \multirow{3}{*}{$\begin{array}{l}\text { Normal Sperm } \\
(\%)\end{array}$} & $\mathrm{T}_{0}$ & $88.6 \pm 1.2^{\mathrm{A}}$ & $89.2 \pm 1.1^{\mathrm{A}}$ & $84.6 \pm 0.4^{\mathrm{A}}$ & $85.4 \pm 1.2^{\mathrm{A}}$ & $84.2 \pm 1.7^{\mathrm{A}}$ \\
\hline & $\mathrm{T}_{24}$ & $70.1 \pm 1.0^{\mathrm{c}, \mathrm{B}}$ & $82.9 \pm 0.5^{\mathrm{a}, \mathrm{B}}$ & $81.7 \pm 0.5^{\mathrm{a}, \mathrm{B}}$ & $77.9 \pm 0.6^{\mathrm{b}, \mathrm{B}}$ & $77.6 \pm 2.1^{b, B}$ \\
\hline & $\mathrm{T}_{48}$ & $51.6 \pm 1.0^{\mathrm{c}, \mathrm{C}}$ & $76.6 \pm 0.4^{\mathrm{a}, \mathrm{C}}$ & $78.8 \pm 0.7^{\mathrm{a}, \mathrm{C}}$ & $70.4 \pm 0.2^{\mathrm{b}, \mathrm{C}}$ & $71.0 \pm 4.0^{\mathrm{b}, \mathrm{C}}$ \\
\hline
\end{tabular}

${ }^{\mathrm{a}-\mathrm{d}}$ Values in the same row with different superscript letters differ significantly $(\mathrm{P}<0.05)$

${ }^{\text {A-C }}$ Values in the same column with different superscript letters differ significantly $(\mathrm{P}<0.05)$ presence of isoflavonoids, which have been reported to manifest antioxidant, antimicrobial, antiprotozoal, and antifungal activities (Cattani et al., 2012). Further, Marquele et al. (2005) reported that Brazilian propolis was determined to exhibit antioxidant effect. Meanwhile, propolis is known to beactive against (gram-positive) bacteria, viruses, fungi, and parasites (Alencar et al., 2007 and Morsy et al., 2013). It has been proven to be $100 \%$ effective against some parasites such as lethal protozoa and would also decrease inflammation associated with parasite infection (Higashi and de Castro, 1994). Several authors have confirmed the activity of propolis volatiles against different microorganisms such as Gram-positive bacteria: Staphylococcus aureus, Staphylococcus epidermidis, Micrococcus glutamicus, Bacillus subtilis , Bacillus cereus, Sarcinalutea, Streptococcus pyogenes, Streptococcus mutans, Streptococcus faecalis (Silva et al., 2008; Falcão et al., 2010; Popova et al., 2010; Duran et al. 2011; Ordóñez et al., 2011 and Tran et al., 2012), and also Gram-negative bacteria such as Escherichia coli, Enterobacter cloacae, Klebsiellapneumoni, Pseudomonas aeruginosa (Silva et al., 2008 and Duran et al., 2011). 


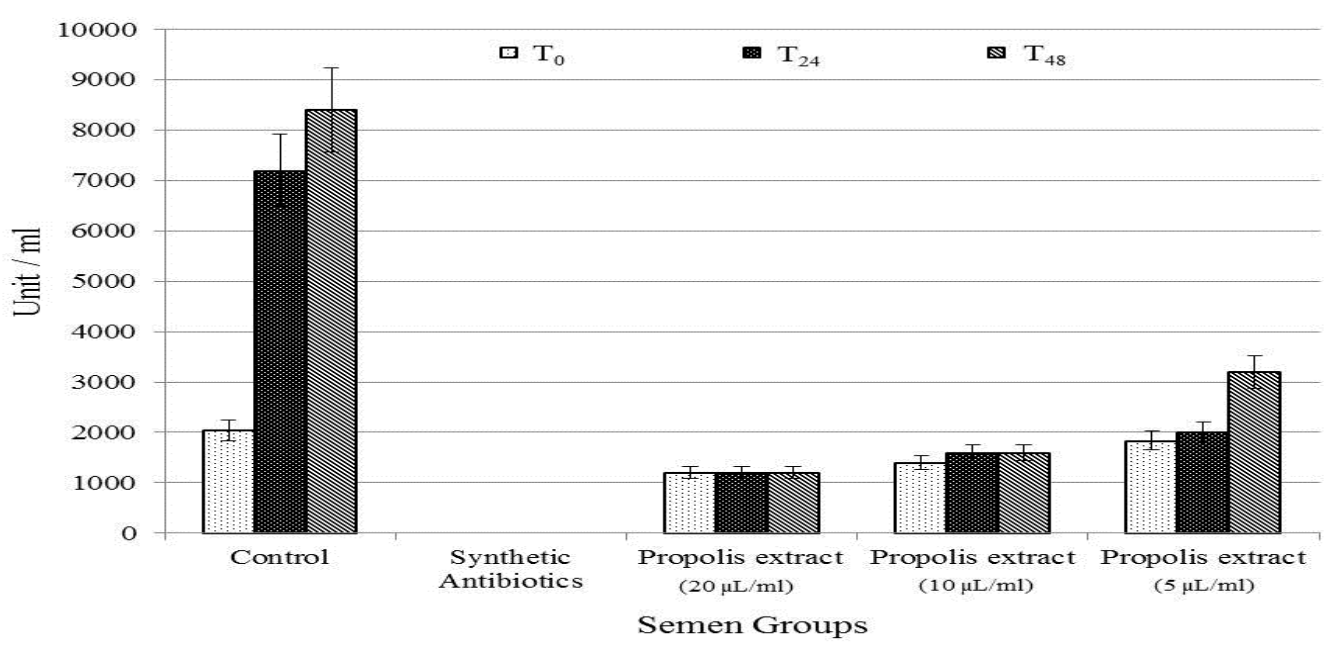

Figure 1. Effect of adding deferent levels of propolis extract to Holstein bulls' semen extender on colonyforming unit (CFU) formation during cooled preservation (mean \pm SEM)

\section{CONCLUSION}

The results of the current pilot study revealed the efficiency of adding propolis ethanolic extract to semen extender on enhancing cooled storage of bull sperm in regard to physical characteristics and microbial contamination. Further studies are needed to evaluate the influence of propolis extract supplementation on potential fertility of spermatozoa.

\section{ACKNOWLEDGMENT}

The author is greatly indebted to Dt. Amr S. Morsy for providing the purified propolis extract. Sincere gratitude is also extended to Mr. Sameh Soliman, supervisor of the Artificial Insemination Center of the West Noubaria Rural Development Project, Alexandria, Egypt, for providing all the facilities to perform the work.

\section{REFERENCES}

Agarwal, A., A. Ramadan, and A. B. Mohamed, 2003. Role of reactive oxygen species in the pathophysiology of human reproduction. Fert. Steril., 79: 829-843.

Alam, M. G. S., S. Yeashmin, F. Y. Bari, and B. Mishra, 2005. The effect of duration of preservation of the quality of chilled bull semen. The Bangladesh Veterinarian, 22: 16-22.

Alencar, S. M., T. L. C. Oldoni, M. L. Castro, I. S. R. Cabral, C. M. Costa-Neto, J. A. Cury, P. L. Rosalen, and M. Ikegaki, 2007. Chemical composition and biological activity of a new type of Brazilian propolis: red propolis. Journal of Ethnopharmacology, 113(2): 278-283.

Almaraz-Abarca N., M. da Graça Campos, J. A. Ávila-Reyes, N.Naranjo-Jiménez, J. Herrera Corral, and L. S. González-Valdez, 2007. Antioxidant activity of polyphenolic extract of monofloral honeybee-collected pollen from mesquite (Prosopisjuliflora, Leguminosae) Journal of Food Composition and Analysis. 20(2):119-124.
Bankova, V., 2005. Chemical diversity of propolis and the problem of standardization. J Ethnopharmacology, 100: 114-117.

Barszcz, K., D. Wiesetek, M. Wąsowicz, and M. Kupczyńska, 2012. Bull Semen Collection and Analysis for Artificial Insemination. J. Agric. Sci., 4: 1-10.

Cardoso,S. M., M. Ribeiro, I. L. Ferreira, and A. Cristina Rego, "Northeast Portuguese propolis protects against staurosporine and hydrogen peroxide-induced neurotoxicity in primary cortical neurons," Food and Chemical Toxicology, vol. 49, no. 11, pp. 2862-2868, 2011.

Cattani, M., T. Franco, B. Lucia, and S. Stefano, 2012. Synthetic and natural polyphenols with antioxidant properties stimulate rumen microbial growth in vitro, Animal Production Science, 52: 44-50.

Duran N., M. Muz, G. Culha, G. Duran, and B. Ozer, 2011. GC-MS analysis and antileishmanial activities of two Turkish propolis types. Parasitology Research, 108(1): 95-105.

Falcão, S. I., M. Vilas-Boas, L. M. Estevinho, C. Barros, M. R. M. Domingues, and S. M. Cardoso, 2010 "Phenolic characterization of Northeast Portuguese propolis: usual and unusual compounds," Analytical and Bioanalytical Chemistry, 396: 887-897.

Fokt, H., A. Pereira, A. M. Ferreira, A. Cunha, and C. Aguiar, "How do bees prevent hive infections? The antimicrobial properties of propolis," in Current Research, Technology and Education Topics in Applied Microbiology and Microbial Biotechnology, A. Mendez-Vilas, Ed., vol. 1 of Microbiology Book Series-Number 2, pp. 481493, 2010.

Foote, R. H., C. C. Brochkett, and M. T. Kaproth, 2002. Motilityand fertilizing of bull sperm in whole milk extender containing antioxidants. Anim. Reprod. Sci., 71: 13-23.

Higashi, K. O. and S. L. de Castro, 1994. Propolis extracts are effective against Trypanosomacruzi 
and have an impact on its interaction with host cells. Journal of Ethnopharmacology. 43: 149155.

Jha, P. K., A. K. Paul, M. B. Rahman, M. Tanjim, F. Y. Bari, and M. G. Alam, 2013. Improvement of preservation quality of chilled bull semen using $\alpha$ tocopherol as an antioxidant. J. Emb. Trans. 28: 31-39.

Johanson, L., W. F. Berndtson, and B. W. Pickett, 1976. An improved method for evaluating acrosomes of bovine spermatozoa .J.Anim. Sci, 42: 951- 954.

Kujumgiev A., I. Tsvetkova, Y. Serkedjieva, V. Bankova, R. Christov, and S. Popov, 1999. Antibacterial, antifungal and antiviral activity of propolis of different geographic origin. Journal of Ethnopharmacology. 64(3): 235-240.

Marcucci, M., 1995. Propolis: chemical composition, biological properties and therapeutic activity. Apidologie, 26: 83-99.

Marquele, F. D., V. M. Di Mambro, S. R. Georgetti, R. Casagrande, Y. M. Valim, and M. J. Fonseca, 2005. Assessment of the antioxidant activities of Brazilian extracts of propolis alone and in topical pharmaceutical formulations, J. Pharmaceutical Biomed. Analysis, 39: 455-462.

Mirzoeva O. K., R. N. Grishanin, and P. C. Calder, 1997. Antimicrobial action of propolis and some of its components: the effects on growth, membrane potential and motility of bacteria. Microbiological Research. 152 (3): 239-246.

Morrell, J. M., 2006. Update on semen technologies for animal breeding. Reprod. Domest. Anim., 41(1): 63-67.

Morsy A. S., A. L. Abdalla, Y. A. Soltan, S. M. Sallam, K. M. El-Azrak, H. Louvandini, and S. M. Alencar, 2013. Effect of Brazilian red propolis administration on hematological, biochemical variables and parasitic response of Santa Inês ewes during and after flushing period.Troical Animal Health and Production, 45: 1609-1618.

Morsy A. S., Y. A. Soltan, S. M. Sallam, M. Kreuzer, S. M. Alencar, and A. L. Abdalla, 2015. Comparison of the in vitro efficiency of supplementary beepropolis extracts of different origin in enhancing the ruminaldegradability of organic matter and mitigating the formation of methane. Anim. Feed Sci. Technol., 199: 51-60.

Morsy, A. S., A. L. Abdalla, Y. A. Soltan, S. M. Sallam, K. M. El-Azrak, H. Louvandini, and S. M. Alencar, 2013. Effect of Brazilian red propolis administration on hematological, biochemical variables and parasitic response of Santa Inês ewes during and after flushing period.Trop. Anim. Health Prod., 45: 1609-1618.

Munsi, M. N., M. M. U. Bhuiyan, S. Majumder, and M. G. S. Alam, 2007. Effects of exogenous glutathion on the quality of chilled bull semen. Reprod. Dom. Anim., 42: 358-362.

Nader M. A., D. S. El-Agamy, and G. M. Suddek, 2010. Protective effects of propolis and thymoquinone on development of atherosclerosis in cholesterol-fed rabbits. Archives of Pharmacal Research. 33(4): 637-643.

National Research Council (NRC). Nutrient Requirement for Dairy Cattle. Seventh revised edition, 2001.

Ordóñez R. M., I. C. Zampini, M. I. N. Moreno, and M. I. Isla, 2011. Potential application of Northern Argentine propolis to control some phytopathogenic bacteria. Microbiological Research. 166 (7): 578-584.

Popova,M. P., K. Graikou, I. Chinou, and V. S. Bankova, 2010. GC-MS profiling of diterpene compounds in Mediterranean propolis from Greece. J AgricFood Chem., 58: 3167-3176.

Salisbury, G. W., N. L. VanDemark, and J. R. Lodge, 1978. Extenders and extension of unfrozen semen. In: Physiology of reproduction and artificial insemination in cattle. San Francisco: W. H. Freeman and Co, Pp: 442-493.

Sannat, C., A. Ajit Nair, S. B. Sahu, S. A. Sahasrabudhe, A. A. Kumar, A. K. Gupta, and R. K. Shende, 2015. Critical sources of bacterial contamination and adoption of standard sanitary protocol during semen collection and processing in semen station. Veterinary World, 8: 631-635.

Scalbert A., I. T. Johnson, and M. Saltmarsh, 2005. Polyphenols antioxidants and beyond. The American Journal of Clinical Nutrition. 81 (1, supplement):215S-217S.

Scazzocchio F., F. D. D'Auria, D. Alessandrini, and F. Pantanella, 2006. Multifactorial aspects of antimicrobial activity of propolis. Microbiological Research, 161(4): 327-333.

Sforcin J. M., and V. Bankova, 2011. Propolis: is there a potential for the development of new drugs ? Journal of Ethnopharmacology. ; 133(2): 253-260.

Shukla, M. K., 2005. Correlation of microbial load of cryopreserved semen with quality of neat and cryopreserved murrah buffalo bull semen. Buffalo Bull., 24: 84-87.

Silva B. B., P. L. Rosalen, and J. A. Cury, 2008. Chemical composition and botanical origin of red propolis, a new type of Brazilian propolis Evidence-Based Complementary and Alternative Medicine. 5 (3): 313-316.

Steel, R. G. D., and J. H. Torrie, 1980. Principles and Procedures of statistics: A Biometrical Approach 2nd Edn., McGraw-Hill Book Co. Inc., New York.

Tran, V. H., R. K. Duke, A. Abu-Mellal, and C. C. Duke, 2012. "Propolis with high flavonoid content collected by honey bees from Acacia paradoxa," Phytochemistry, 81: 126-132.

Umthong S., P. Phuwapraisirisan, S. Puthong, and C. Chanchao, 2011. "In vitro antiproliferative activity of partially purified Trigonalaevicepspropolis from Thailand on human cancer cell lines," BMC Complementary and Alternative Medicine, vol. 11, article 37. 
تاثير تدعيم مخفف السائل المنوي للطلائق بمستخلص البروبليس علي الحمل الميكروبي والخصائص الطبيعية للسـائل المنوي المحفوظ بالتبريد

$$
\text { عوض عبد الغني زغلول }
$$

قسم فسيولوجيا الحيوان والدواجن، شعبة الاتتاج الحيواني، مركز بحوث الصحراء، مصر

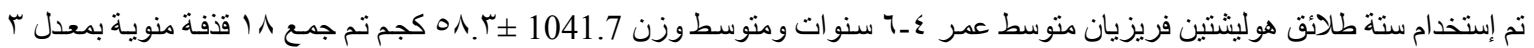

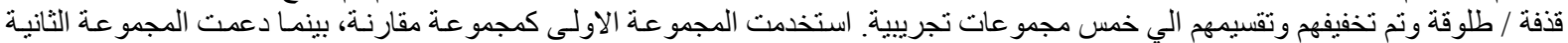

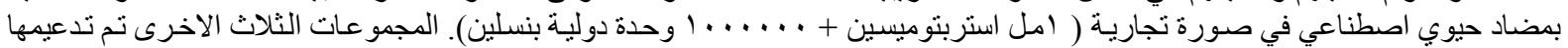

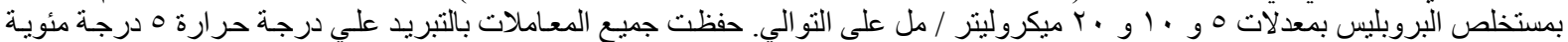

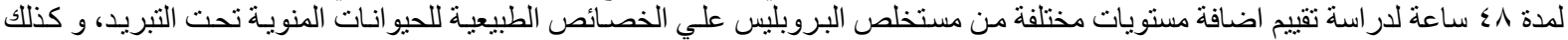

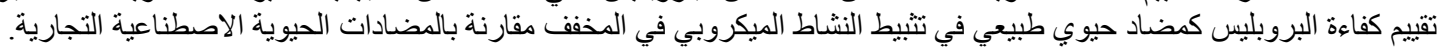

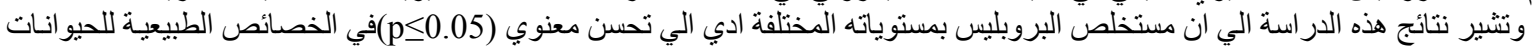

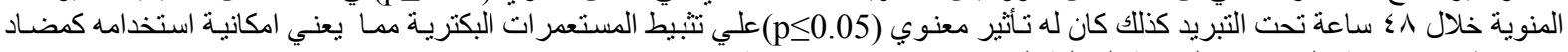
حيوي طبيعي مقارنة بالمضادات الحيوية المخلقة الموجودة في صورة كالثرة تجارية. 